\title{
Uji Aktivitas Antibakteri Sediaan Gel Ekstrak Daun Sereh (Cymbopogon nardus L. Rendle) terhadap Bakteri Staphylococcus aureus Penyebab Jerawat
}

\author{
(Anti Bacterial Activity Test Of Extract Gel Formulation Of Lemongrass Leaves (Cymbopogon \\ nardus L. Rendle) on Staphylococcus aureus Acne Causing Bacteria)
}

\author{
Sarlina*, Abdul Rahman Razak", Muhamad Rinaldhi Tandah* \\ Jurusan Farmasi, Fakultas MIPA, Universitas Tadulako, Palu
}

Article Info:

Received: 08Juni 2017

in revised form: 22 Juni 2017

Accepted: 30 Juni 2017

Available Online: 01Oktober 2017

Keywords:

Lemongrass Leaf Extract, Carbopol,

Anti Bacterial Activity

Corresponding Author:

Sarlina

Abd. Rahman Razak

Muhamad Rinaldhi Tandah

Jurusan Farmasi, Fakultas MIPA,

Universitas Tadulako, Palu,

Indonesia

Phone :+62 812-4133-3308

Email: sarlina964@gmail.com

\begin{abstract}
The research on activity test of anti bacterial effect gel of citronella leaf (Cymbopogon nardus L. Rendle) on Staphylococcus aureushad been conducted. This research aims to determine the offect of carbopol concentration variation, and the concentration of extract, and the combination of both against gel stability and antibacterial activity to Staphylococcus aureus. Lemongrass leaf extract (Cymbopogon nardus L. Rendle) was obtained by maceration with $96 \%$ ethanol. The research design used ANOVA data analysis of complete randomized design of factorial pattern with variation of extract concentration of 5\%,10\%, 15\%, 20\% and carbopol as gel base with homogeneity concentration, $\mathrm{pH}$ test, viscosity test, and anti bacterial activity test. The results reveal that variation of extract concentration affect the stability and activity of anti bacterial gel of lemongrass leaf extract. Variations in carbopolic concentration affect antibacterial activity but do not affect stability. Combination of vatiation of carbopoly concentration and extract affect anti bacterial activity. A good treatment combination wa obtained on formula $\mathrm{A}_{1} \mathrm{~B}_{4}$, because it had the highest anti-bacterial activity of $14,56 \mathrm{~mm}$.
\end{abstract}




\begin{abstract}
ABSTRAK
Penelitian tentang uji aktivitas antibakteri sediaan gel ekstrak daun sereh (Cymbopogon nardus L.Rendle) terhadap pertumbuhan bakteri Staphylococcus aureus telah dilakukan. Penelitian ini bertujuan untuk mengetahui pengaruh variasi konsentrasi karbopol, konsentrasi ekstrak, dan kombinasi keduanya terhadap stabilitas gel dan aktivitas antibakteri terhadap Staphylococcus aureus. Ekstrak daun sereh (Cymbopogon nardus L.Rendle) diperoleh dengan cara maserasi dengan etanol 96\%. Desain penelitian menggunakan analisis data ANOVA rancangan acak lengkap pola faktorial dengan variasi konsentrasi ekstrak 5\%, 10\%, 15\%, 20\% dan karbopol sebagai basis gel dengan konsentrasi $0,5 \%, 1 \%$ dan 2\%. Evaluasi stabilitas sediaan mencakup uji organoleptis, uji homogenitas, uji $\mathrm{pH}$, uji viskositas, dan uji aktivitas antibakteri. Hasil penelitian menunjukkan bahwa variasi konsentrasi ekstrak mempengaruhi stabilitas dan aktivitas antibakteri gel ekstrak daun sereh (Cymbopogon nardus L.Rendle). Variasi konsentrasi karbopol mempengaruhi aktivitas antibakteri tetapi tidak mempengaruhi stabilitas. Kombinasi variasi konsentrasi karbopol dan ekstrak mempengaruhi aktivitas antibakteri. Kombinasi perlakuan yang baik diperoleh pada formula $\mathrm{A}_{2} \mathrm{~B}_{4}$, karena memiliki aktivitas antibakteri tertinggi yaitu $14,56 \mathrm{~mm}$.
\end{abstract}

Kata Kunci : Ekstrak daun sereh, karbopol, aktivitas antibakteri

\section{PENDAHULUAN}

Kulit merupakan organ terbesar pada tubuh manusia dan merupakan garis pertahanan utama dari serangan infeksi yang berasal dari luar.Kulit mempunyai sistem kekebalan sendiri yang dirusak oleh mikroorganisme (Davies, 1998). Kulit berminyak merupakan salah satu penyebab kulit berjerawat.Pada kulit berminyak, kelenjar sebasea dan keringat terdapat dalam jumlah yang banyak.Banyaknya kelenjar sebum yang dihasilkan dapat menyumbat pori-pori kulit. Proses terjadinya jerawat yaitu ketika keratinin yang lepas bertumpuk di kulit. Penyumbatan terjadi disebabkan oleh salah satu bakteri penyebab jerawat yaitu Staphylococcus aureus sehingga terjadi peradangan.Jerawat dipengaruhi oleh produksi kelenjar minyak yang berlebihan dan keaktifan dari kelenjar sebasea (Ayu,2009).

Staphylococcus aureus merupakan salah satu flora normal yang dapat menyebabkan infeksi beragam pada jaringan tubuh seperti infeksi pada kulit misalnya jerawat dan bisul.Keberadaan bakteri ini, justru diperkirakan terdapat pada 20 persen orang dengan kondisi kesehatan yang tampaknya baik.

Saat ini minat masyarakat untuk memanfaatkan kembali bahan alam bagi kesehatan, terutama obat-obatan dari tumbuhan cenderung meningkat. Menurut WHO Anonim (2004), 80\% populasi dunia telah menggunakan obat-obatan herbal untuk semua aspek kesehatan. Daun sereh adalah salah satu tanaman yang mudah tumbuh di daerah katulistiwa yang diketahui mempunyai bahan antibakteri,memperbaiki kulit dengan mengurangi jerawat.Daun sereh mempunyai substansi lipofilik yang dapat menembus membran sel bakteri.Efek antibakteri daun sereh disebabkan adanya beberapa senyawa aktif dari daun sereh.Daun sereh (Cymbopogon nardus L. Rendle) mengandung senyawa kimia yaitu minyak atsiri, alkaloid, flavonoid, dan polifenol (Anonim, 2004). Tanaman sereh dengan kandungan senyawa seperti minyak atsiri, alkaloid, flavonoid memiliki aktivitas antibakteri yang dapat dibuat sediaan yang aman, nyaman dan praktis untuk digunakan pada jerawat, misalnya sedian gel. Penelitian ini memanfaatkan ekstrak daun sereh(Cymbopogon nardus L. Rendle) untuk dijadikan sebagai bahan aktif sediaan gel jerawat dan dilakukan uji kestabilan sediaan yang meliputi uji organoleptis, uji homogenitas, uji $\mathrm{pH}$, uji viskositas, dan uji aktivitas antibakteridengan variasi konsentrasi ekstrak 5\%, 10\%, 15\%, 20\% dan karbopol sebagai basis gel dengan konsentrasi $0,5 \%$, $1 \%$ dan $2 \%$.

\section{METODE PENELITIAN}

Alat

Cawan porselen, gelas ukur (IWAKI PIREX $^{\circledR}$ ), mortir dan stamper, batang pengaduk, 
corong (IWAKI PIREX ${ }^{\circledR}$ ), tabung reaksi (IWAKI PIREX $^{\circledR}$ ), wadah maserasi, erlenmeyer (IWAKI PIREX $\left.^{\circledR}\right)$, neraca analitik $\left(\right.$ OHAUS $\left.^{\circledR}\right)$, Hot Plate (Vendille $\left.{ }^{\circledR}\right)$, Vacuum Rotary Evaporator $\left(\right.$ EYELA $\left.^{\circledR}\right)$, cawan petri, pH meter (Consort tipe C561), viscometer (Brookfield), jangka sorong,mistar,oven, sendok tanduk, kertas saring, autoklaf (Hiclave hve50), inkubator, pinset, jarum ose, sudip, bunsen, spatula, pot gel, dan laminar air flow (LAF).

\section{Bahan}

Simplisia Daun sereh (Cymbopogon nardus L. Rendle) dan etanol 96\%. Bahan untuk uji aktivitas antibakteri adalah Nutrient Agar (NA), DMSO, larutan Mc.Farland No. 0,5, NaCl 0,9 \%, isolat bakteri Staphylococcus aureuss. Bahan untuk pembuaatan gel adalahkarbopol 940, propilenglikol, metil paraben, trietanolamin, gliserin, aquadest.

\section{Pengumpulan dan Pengolahan Daun Sereh}

Daun sereh(Cymbopogon nardus L. Rendle) diperoleh dari Desa Tanahmea Kecamatan Banawa Selatan Kabupaten Donggala, Sulawesi Tengah dan telah dideterminasi di Laboratorium Biodiversitas FMIPA Universitas Tadulako. Sampel terlebih dahulu dilakukan sortasi basah kemudian dicuci pada air yang mengalir, setelah itu sampel tersebut dirajang kecil. Untuk menghilangkan kandungan air pada sampel dilakukan pengeringan dengan cara diangin-anginkan lalu dilakukan sortasi kering kemudian dibuat menjadi serbuk kasar lalu disimpan dalam wadah yang tertutup baik, sehingga didapatkan simplisia daun sereh untuk siap diekstraksi.

\section{Pembuatan Ekstrak menurut Sampurno (2004)}

Simplisia yang telah kering diekstraksi dengan metode maserasi menggunakan etanol $96 \%$ dan diaduk sesekali selama 24 jam. Didiamkan selama 72 jam lalu maserat ditampung (maserat pertama). Proses ekstraksi diulang kembali dengan cara yang sama. Maserat yang diperoleh dipekatkan dengan Rotary evaporator.

\section{Rancangan Penelitian}

Rancangan penelitian ini dilakukan dengan cara metode difusi sumuran. Penelitian ini menggunakan rancangan acak lengkap faktorial dengan 2 faktor yaitu faktor A adalah konsentrasi karbopol yang terdiri dari 3 taraf $(0,5 \% ; 1 \%$ dan $2 \%)$ dan faktor B adalah ekstrak yang terdiri dari 4 taraf (5\%,10\%, 15\%, dan 20\%). Total data sebanyak 12 dan dilakukan replikasi sebanyak 3 kali sehingga total perlakuan sebanyak 36. Rancangan acak lengkap faktorial $3 \times 4$ dapat dilihat pada Tabel 1 berikut :

Tabel 1. Rancangan Penelitian

\begin{tabular}{|c|c|c|c|c|}
\hline & B1 & B2 & B3 & B4 \\
\hline A1 & A1B1 & A1B2 & A1B3 & A1B4 \\
\hline A2 & A2B1 & A2B2 & A2B3 & A2B4 \\
\hline A3 & A3B1 & A3B2 & A3B3 & A3B4 \\
\hline
\end{tabular}

Keterangan :

A1:Karbopol 0,5\%

A2:Karbopol $1 \%$

A3:Karbopol 2\%

B1: Konsentrasi 5\%

B2: Konsentrasi $10 \%$

B3: Konsentrasi $15 \%$

B4: Konsentrasi 20\%

\section{Pembuatan Gel}

Pembuatan gel ekstrak daun sereh (Cymbopogon nardus L. Rendle) dapat dilihat pada tabel 2. Sediaan gel dapat dibuat dengan cara sebagai berikut : Sejumlah karbopol dibuat dengan mendispersikan karbopol $(0,5 \% ; 1 \% ; 2 \%)$ dengan 50 $\mathrm{ml}$ aquadest yang telah dipanaskan hingga suhu $70^{\circ} \mathrm{C}$, dibiarkan mengembang dan digerus menggunakan stamper sampai homogen, kemudian ditambahkan sejumlah ekstrak daun sereh $(5 \%, 10 \%, 15 \%, 20 \%)$ yang dilarutkan dengan gliserin, ditambahkan trietanolamin dan propilenglikol digerus sampai homogen sampai terbentuk massa gel yang jernih. Setelah itu, ditambahkan metil paraben yang dilarutkan dalam aquadest yang telah dipanaskan sebanyak $15 \mathrm{ml}$, digerus hingga homogen dan ditambahkan sisa aquadest sambil terus digerus hingga gel homogen, lalu dimasukkan dalam wadah. Selanjutkan gel disimpan pada tempat yang gelap pada suhu $10^{\circ} \mathrm{C}-15^{\circ} \mathrm{C}$.

Tabel 2. Formula Gel Ekstrak Daun Sereh

\begin{tabular}{ccc}
\hline Bahan & Kegnaan & $\begin{array}{c}\text { Konsentrasi } \\
(\%)\end{array}$ \\
\hline Ekstrak daun & Zat aktif & $5 \% ; 10 \% ;$ \\
sereh & & $15 \% ; 20 \%$ \\
Carbopol & Gelling agent & $0,5 \% ; 1 \% ;$ \\
Trietanolamin & Alkalizing agent & $3 \%$ \\
Propilenglikol & Kosolven & $15 \%$ \\
Metal paraben & Pengawet & $0,2 \%$ \\
Gliserin & Humektan & $8 \%$ \\
Aquadest & Pelarut & ad $100 \mathrm{ml}$ \\
\hline
\end{tabular}




\section{HASIL DAN PEMBAHASAN}

\section{Ekstraksi Senyawa Aktif Daun Sereh}

Simplisia daun sereh sebanyak $1,016 \mathrm{~kg}$ diekstraksi dengan metode maserasi menggunakan pelarut etanol 96\% sebanyak10 L. Hasil ekstrak kental etanol daun sereh yaitu 174,52 gram. Rendamen yang diperoleh yaitu $17,177 \%$. Maserasi merupakan cara penyariaan sederhana dengan merendam serbuk simplisia dalam cairan penyari (Voigt, 1994). penyari yang digunakan adalah etanol 96\%, karena dapat lebih mudah berpenetrasi kedalam sel, bersifat universal yang mampu menarik semua jenis zat aktif, baik bersifat polar, semipolar, dan non polar, dan juga kadar toksisitasnya rendah.

\section{Evaluasi Stabilitas Gel}

a. Uji organoleptis

Pada pemeriksaan organoleptis dilakukan dengan mengamati perubahan-perubahan bau dan warna dari sediaan gel selama waktu penyimpanan, pengamatan perubahan-perubahan bau dan warna tersebut dilakukan pada hari ke-0, ke-7, ke-14, ke-21, dan ke-28. Seperti pada tabel 3 dan 4.

Tabel 3.Organoleptis Aroma Gel Ekstrak Daun Sereh

\begin{tabular}{cccccc}
\hline Perlakuan & H-0 & H-7 & H-14 & H-21 & H-28 \\
\hline A1B1 & + & + & + & + & + \\
A1B2 & + & + & + & + & + \\
A1B3 & + & + & + & + & + \\
A1B4 & + & + & + & + & + \\
A2B1 & + & + & + & + & + \\
A2B2 & + & + & + & + & + \\
A2B3 & + & + & + & + & + \\
A2B4 & + & + & + & + & + \\
A3B1 & + & + & + & + & + \\
A3B2 & + & + & + & + & + \\
A3B3 & + & + & + & + & + \\
A3B4 & + & + & + & + & + \\
\hline
\end{tabular}

Keterangan: $(+)=$ aroma khas ekstrak

Hasil pengamatan organoleptis terhadap 12 formula yang diamati secara visual menunjukkan bahwa semua sediaan memiliki aroma khas daun sereh, tidak ada aroma lain seperti tengik dan apek yang tercium mulai dari hari ke-0 sampai dengan hari ke-28 pengamatan, dan untuk warna sediaan dari masing-masing formula yaitu karbopol $0,5 \%$ ekstrak 5\% (A1B1), karbopol 0,5\% ekstrak 10\% (A1B2), karbopol 1\% ekstrak 10\% (A2B2), karbopol 1\% ekstrak 15\% (A2B3), karbopol 2\% ekstrak 15\% (A3B3) dan karbopol 2\% ekstrak 20\% (A3B4) berwarna hijau tua, karbopol 2\% ekstrak 5\% (A3B1) dan karbopol 2\% ekstrak 10\% (A3B2) berwarna hijau kecoklatan, karbopol 0,5\% ekstrak 20\% (A1B4) dan karbopol 1\% ekstrak 20\% (A2B4) berwarna hijaukehitaman, karbopol 0,5\% ekstrak 15\% (A1B3) berwarna hijau dan karbopol 1\% ekstrak 5\% (A2B1) berwarna hijau kekuningan mulai dari hari ke 0 sampai dengan hari ke 28 .

Tabel 4. Organoleptis Warna Gel Ekstrak Daun Sereh

\begin{tabular}{cccccc}
\hline Perlakuan & H-0 & H-7 & H-14 & H-21 & H-28 \\
\hline A1B1 & ht & ht & ht & ht & ht \\
A1B2 & ht & ht & ht & ht & ht \\
A1B3 & h & h & h & H & h \\
A1B4 & hk & hk & hk & hk & hk \\
A2B1 & hku & hku & hku & hku & hku \\
A2B2 & ht & ht & ht & ht & ht \\
A2B3 & ht & ht & ht & ht & ht \\
A2B4 & hk & hk & hk & hk & ht \\
A3B1 & hc & hc & hc & hc & hc \\
A3B2 & hc & hc & hc & hc & hc \\
A3B3 & ht & ht & ht & ht & ht \\
A3B4 & ht & ht & ht & ht & ht \\
\hline
\end{tabular}

Keterangan:

(hku) : hijau kekuningan

(hc) : hijau kecoklatan

(h) : hijau

(ht) : hijau tua

(hk) : hijau kehitaman

b. Uji homogenitas

Pengujian homogenitas dilakukan gengan cara dioleskan sediaan gel di atas kaca objek, kemudian diratakan. Diamati homogenitas bahan aktif di dalam basis dengan melihat bagian-bagian yang tidak tercampur dengan baik pada sediaan gel. Seperti pada tabel dibawah :

Tabel 5. Homogenitas Sediaan Gel Ekstrak Daun Sereh

\begin{tabular}{cc}
\hline Kelompok Perlakuan & Homogenitas \\
\hline A1B1 & + \\
A1B2 & - \\
A1B3 & - \\
A1B4 & - \\
A2B1 & + \\
A2B2 & + \\
A2B3 & + \\
A2B4 & + \\
A3B1 & + \\
A3B2 & + \\
A3B3 & + \\
A3B4 & + \\
\hline
\end{tabular}


Keterangan :

$+\quad:$ Homogen

- : Tidak Homogen

Pada hasil pemeriksaan homogenitas sediaan gel terhadap 12 formula mulai dari hari ke-1 sampai hari ke-28 menunjukkan bahwa 9 formula yaitu A1B1, A2B1, A2B2, A2B3, A2B4, A3B1, A3B2 A3B3, A3B4 tidak memperlihatkan adanya butir-butir kasar atau partikel di dalam gel serta persamaan warna yang merata, sehingga dapat disimpulkan sediaan tersebut homogen dan pada saat dioleskan sediaan tidak meninggalkan bekas warna hijau dari gel tersebut sedangkan 3 formula yaitu A1B2, A1B3, A1B4 dari 12 sediaan tidak homogen secara fisik karena terdapat butiran kasar atau gumpalan. Hal ini menunjukkan bahwa bahan-bahan gel yang digunakan dalam formulasi ada yang tidak terlarut dan tercampur sempurna.Pemeriksaan homogenitas sediaan terhadap 8 formula mulai dari hari ke 0 sampai dengan hari ke 28 menunjukkan bahwa semua sediaan homogen secara fisik karena tidak terlihat butiran kasar atau gumpalan. Hal ini terjadi disebabkan karena adanya zat aktif yang kurang kompatable dengan zat tambahan.

c. Uji pH

Pada pengukuran $\mathrm{pH}$ dilakukan dengan cara mencelupkan $\mathrm{pH}$ meter ke dalam sediaan gel. Dan pengukuran dilakukan pada hari ke-0, ke-7, ke-14, ke-21, dan ke-28. Seperti pada gambar di bawah :

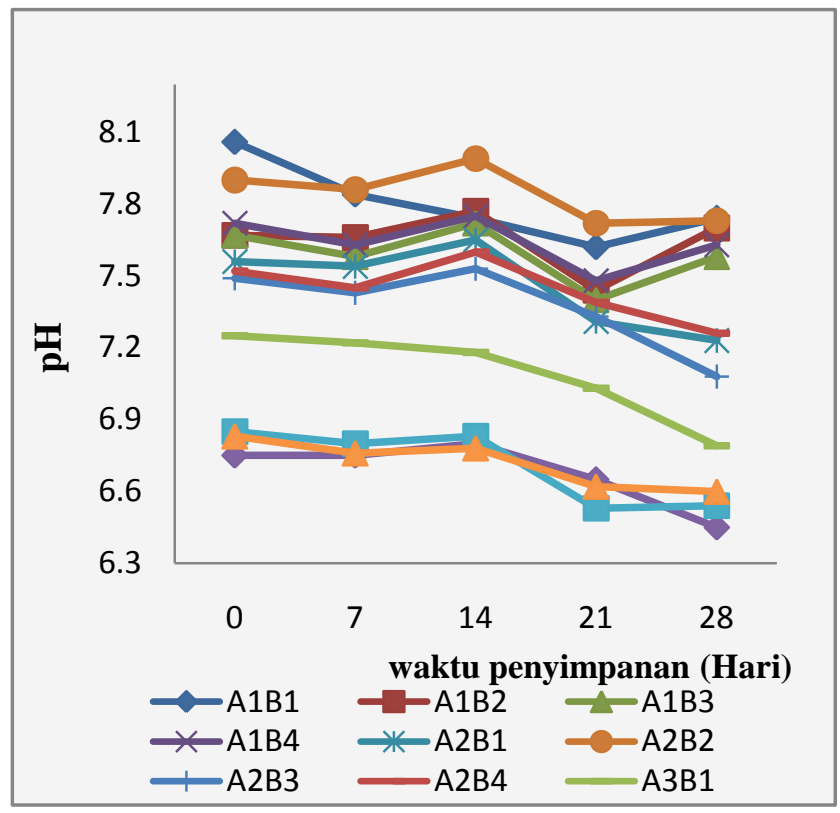

Gambar 1.Grafik hubungan antara $\mathrm{pH}$ dan waktu penyimpanan terhadap sediaan gel.
Uji pH bertujuan untuk melihat apakan sediaan yang dibuat mempunyai nilai $\mathrm{pH}$ yang sesuai dan bisa diterima oleh kulit. Gel yang tidak sesuai dengan $\mathrm{pH}$ kulit akan dapat mengakibatkan iritasi pada kulit.

Pemeriksaan evaluasi $\mathrm{pH}$ sediaan gel ekstrak daun sereh terhadap 12 formula dengan menggunakan alat $\mathrm{pH}$ meter, $\mathrm{pH}$ awal pembuatan sediaan gel ekstrak daun sereh berkisar 6,80 sampai 8,06 dan pada hari ke $28 \mathrm{pH}$ sediaan gelekstrak daun sereh berkisar 6,44 sampai 7,65. Hasil penurunan $\mathrm{pH}$ dapat dilihat pada gambar 1 yang menunjukkan bahwa terjadi penurunan $\mathrm{pH}$ dari hari ke-0 sampai hari ke-28. Rentang penurunan $\mathrm{pH}$ terendah adalah 0,30 dan rentang penurunan $\mathrm{pH}$ tertinggi adalah 0,95 . pHsediaan gelekstrak daun sereh tersebut tidak sesuai dengan $\mathrm{pH}$ kulit yaitu sekitar 4,5 - 6,5. Hal ini disebabkan karena $\mathrm{pH}$ dari ekstrak basa yaitu sekitar 7,04 dan $\mathrm{pH}$ basis basa yaitu 7,73. Untuk itu agar gel tersebut dapat digunakan pada kulit perludilakukan penelitian lebih lanjut terhadap formula agar sesuai dengan $\mathrm{pH}$ kulit.

\section{d. Uji Viskositas}

Pengujian viskositas sediaan dilakukan menggunakan viskometer Brookfield dengan mencelupkan spindle no.6 ke dalam sediaan gel. Lalu diukur viskositasnya. Pengukuran di lakukan pada hari ke-0, ke-7, ke-14, ke-21, dan ke-28. Seperti pada gambar di bawah :

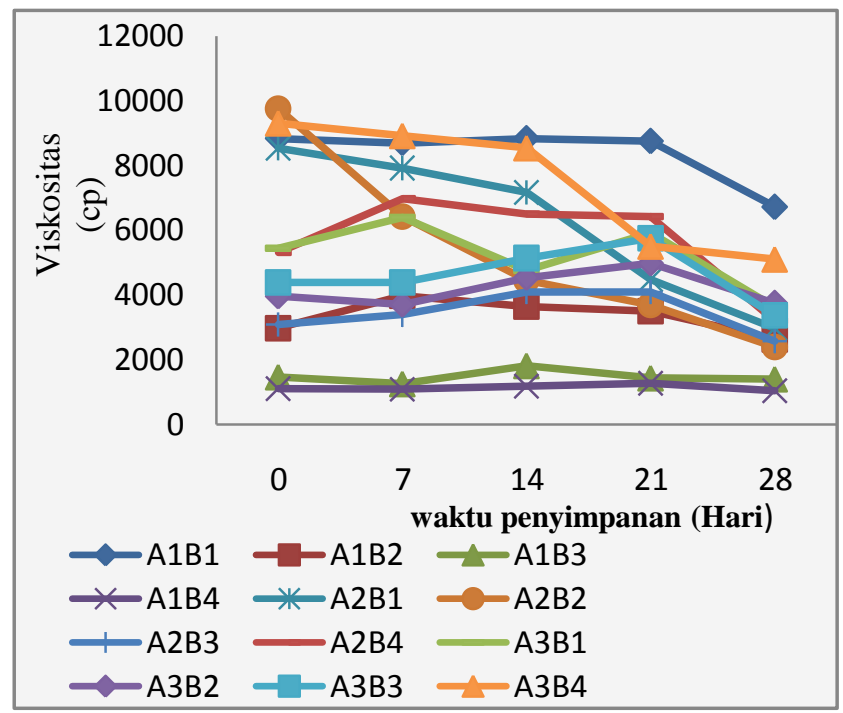

Gambar 2. Grafik hubungan viskositas sediaan dan waktu penyimpanan. 
Setelah dibuat, gel memiliki rentang viskositas dari $1100 \mathrm{cp}$ sampai 9305,33 cp. Setelah penyimpanan, viskositas sediaan memiliki rentang mulai $1033 \mathrm{cp}$ sampai $5100 \mathrm{cp}$, yang berarti bahwa penurunan viskositas setelah penyimpanan dengan selisih penurunan dari 67 cpsampai 4205,33 cp selama penyimpanan. Hal ini disebabkan karena selama penyimpanan sediaan lebih asam yang mengakibatkan jumlah gugus karboksilat yang terionkan berkurang sehingga tolak menolak antar gugus karboksil yang menyebabkan terjadinya pengembangan struktur karbopol menurun. Tetapi, penurunan dan kenaikan viskositas yang dialami sediaan mempengaruhi syarat untuk viskositas gel jerawat yaitu $2000 \mathrm{cp}-4000 \mathrm{cp}$.

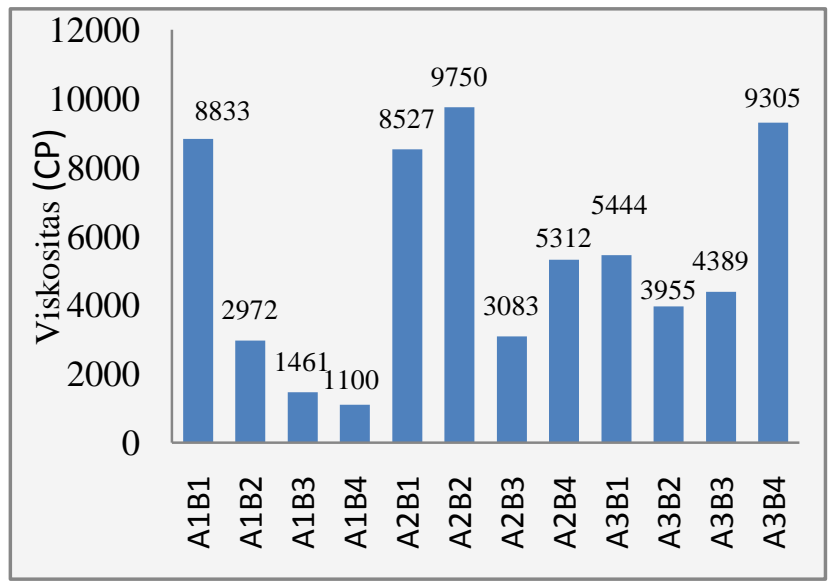

Gambar 3. Grafik hubungan kombinasi karbopol ekstrak terhadap viskositas sediaan gel ekstrak daun sereh.

Berdasarkan gambar 3, sediaan dengan menggunakan karbopol 1\% dan ekstrak 10\% (A2B2) merupakan sediaan dengan viskositas yang tertinggi. Tetapi, sediaan ini dinyatakan tidak stabil dalam viskositas. karena tidak memenuhi range viskositas untuk gel jerawat. dimana sediaan yang stabil dan memenuhi syarat viskositas untuk gel jerawat yaitu sediaan dengan menggunakan karbopol $0,5 \%$ dan ekstrak 10\% (A1B2), karbopol 1\% dan ekstrak 15\% (A2B3) dan karbopol 2\% dan ekstrak 10\% (A3B2).

Faktor karbopol dan ekstrak nilai tertinggi yang diperoleh pada penggunaan karbopol 2\% dan ekstrak 20\% (A3B4) yaitu 8916,667 cpdan terendah pada penggunaan karbopol 0,5\% dan ekstrak $20 \%$ (A1B4) yaitu $1100 \mathrm{cp}$. Hasil analisis statistik SPSS menunjukkan bahwa variasi konsentrasi karbopol berpengaruh karena memiliki perbedaan yang signifikan, begitu pula dengan konsentrasi ekstrak berpengaruh terhadap viskositas karena memiliki perbedaan yang signifikan

\section{Hasil Uji Aktivitas Efek Antibakteri Gel Ekstrak Daun Sereh}

Uji aktivitas antibakteri sediaan gel ekstrak daun sereh dilakukan pada 12 formula dengan replikasi sebanyak 3 kali menggunakan metode difusi dengan cara sumuran terhadap bakteri Staphylococcus aureus. Hasilnya dapat Gambar 4.

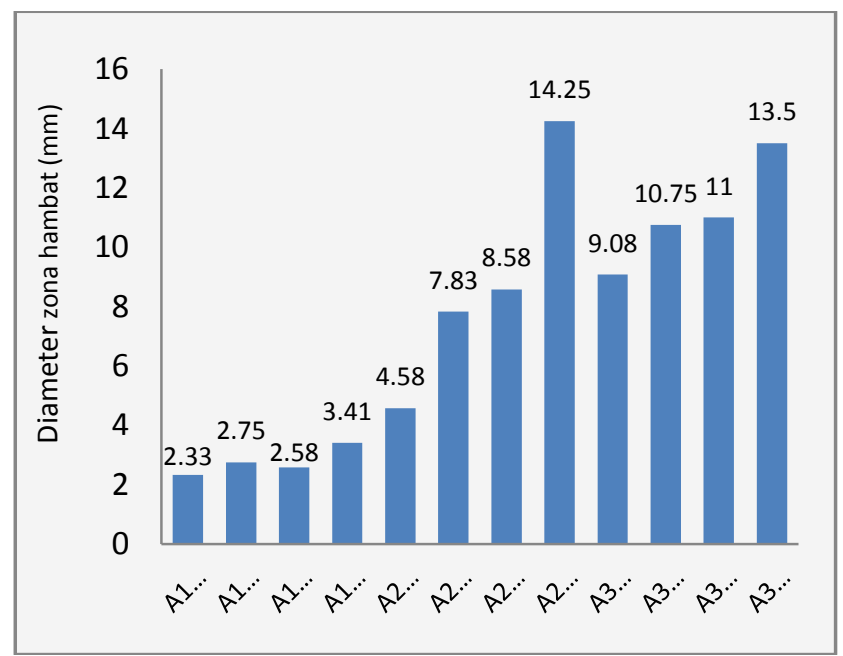

Gambar 4. Grafik hubungan kombinasi karbopol ekstrak terhadap diameter daerah hambat gel ekstrak daun sereh.

Berdasarkan hasil pengukuran diameter zona hambat dari sediaan gel ekstrak daun sereh dari 12 formula diperoleh hasil dari masing-masing konsentrasi secara berturut-turut A1B1, A1B2, A1B3, A1B4, A2B1, A2B2, A2B3, A2B4, A3B1, A3B2, A3B3, dan A3B4 adalah 2,33 mm, 2,75 mm, 2,58 mm, 3,41 mm, $4.58 \mathrm{~mm}, 7,86 \mathrm{~mm}, 8,583 \mathrm{~mm}$, $14,25 \mathrm{~mm}, 9,083 \mathrm{~mm}, 10,75 \mathrm{~mm}, 11 \mathrm{~mm}$ dan 13,5 $\mathrm{mm}$. Pada penelitian ini tidak hanya konsentrasi daun sereh dalam formula yang berpengaruh terhadap besarnya zona hambat yang terbentuk melainkan jumlah atau volume gel yang yang dimasukkan ke dalam lubang sumuran sangat berpengaruh terhadap zona hambat yang terbentuk. Volume gel yang dimasukkan ke dalam lubang sumuran yaitu $0,10 \mu$. Menurut Davis dan Stout (1971) dalam Arista (2013), berdasarkan zona jernih atau zona bening yang terbentuk, daya hambat dikelompokkan menjadi 4 kelompok yaitu sangat kuat bila zona hambat $>20$ $\mathrm{mm}$, kuat 10-20 mm, sedang 5-10 mm dan lemah $<5$ mm. Sediann gel A1B1, A1B2, A1B3, A1B4, A2B1, termasuk dalam sediaan yang memberikan daya 
hambat yang lemah terhadap pertumbuhan bakteri Staphylococcus aureus, karena zona hambat dari formula gel A1B1, A1B2, A1B3, A1B4 dan A2B1 adalah kurang dari lima millimeter $(<5 \mathrm{~mm})$. Sediaan gel A2B2, A2B3, A3B1 termasuk dalam sedian gel yang memberikan daya hambat yg sedang yaitu terhadap bakteri Staphylococcus aureus, karena zona hambat formula gel A2B2, A2B3 dan A3B1 adalah 5-10 mm Sedangkan sediaan gel A2B4, A3B2, A3B3 dan A3B4 tergolong dalam sediaan yang memberikan daya hambat yang kuat terhadap bakteri Staphylococcus aureus, karena zona hambat formula gel A2B4, A3B2, A3B3 dan A3B4 adalah 10-20 mm.

Hasil statistik menunjukkan bahwa pada analisis pengaruh hubungan antara ukuran zona hambat dapat dipengaruhi oleh kepadatan media biakan, kecepatan difusi antibiotik, konsentrasi antibiotik, sensitivitas organisme terhadap antibiotik, dan interaksi antibiotik, dengan media, Hal ini sesuai dengan literatur menurut Hermita (2006), pengaruh ukuran zona hambat dipengaruhi olehkecepatan difusi antibiotik, konsentrasi antibiotik, sensitivitas organisme terhadap antibiotik, dan interaksi antibiotik, dengan media. Demikan pula halnya pada analisis hubungan antara kombinasi karbopol dan ekstrak terhadap antibakteri juga menunjukkan adanya perbedaan yang signifikan. Hal ini disebabkan karena semakin tinggi konsentrasi ekstrak maka aktivitas aktibakteri semakin besar.

Perlakuan dengan diameter daerah hambat yang baik yaitu diameter yang memiliki daerah hambat yang lebih besar dibanding dengan diameter daerah hambat yang lebih kecil.Dalam penelitian ini dapat disimpulkan bahwa kombinasi perlakuan yang baik yaitu penggunaan karbopol $1 \%$ dan ekstrak $20 \%$ (A2B4) karena memiliki daerah hambat yang lebih besar. Penelitian ini perlu dilanjutkan dengan pemisahan senyawa aktif sebagai antibakteri dari daun sereh untuk pembuatan sediaan gel agar dapat sesuai dengan sediaan yang beredar dipasaran. Selain itu, perlu dikembangkan sediaan yang sesuai dengan $\mathrm{pH}$ kulit agar dapat digunakan secara klinis

\section{KESIMPULAN}

Berdasarkan hasil penelitian, dapat disimpulkan bahwa :

1. Variasi konsentrasi karbopol berpengaruh terhadap viskositas dan aktivitas antibakteri, yaitu konsentrasi karbopol 1\% (A2) memberikan nilai tertinggi viskositas $6668,25 \mathrm{cp}$.

2. Variasi konsentrasi ekstrak berpengaruh terhadap viskositas dan aktivitas antibakteri, yaitu konsentrasi ekstrak 5\% (B1) memberikan nilai tertinggi viskositas $7601,78 \mathrm{cp}$ dan konsentrasi ekstrak 15\% (B3) memberikan nilai terkecil viskositas 2977,89 cp.

3. Kombinasi variasi konsentrasi karbopol dan ekstrak menunjukkan adanya interaksi terhadap viskositas dan aktivitas antibakteri, kombinasi perlakuan yang baik yaitu penggunaan karbopol $1 \%$ dan ekstrak 20\% (A2B4).

\section{DAFTAR PUSTAKA}

Anonim. (2004). Standar Pelayanan Farmasi Di Rumah Sakit. Kemenkes RI No. 1197/MENKES/SK/X/2004.

Ayu, S. (2009). Cara Ampuh Mengobati Jerawat, Buana Pustaka, Yogyakarta.

Aziz. (2010). Uji Aktivitas Antibakteri Ekstrak Etanol Daun Dan Umbi Bakung Putih (Crinum aciaticum L.) Terhadap Bakteri Penyebab Jerawat,Skripsi, Fakultas Kedokteran Dan Ilmu Kesehatan Universitas Islam Negeri (UIN) Syarif Hidayatullah, Jakarta.

Davies. (1998). Mengatasi Masalah Kulit, Yayasan Spritia, Jakarta.

Harmita. (2006). Buku Ajar Analisis Fisikokimia. Depok: Departemen Farmasi Fakultas Matematika dan Ilmu Pengetahuan Alam Universitas Indonesia, 15-22.

Sampurno. H. (2004). Ketentuan Pokok Pengelompokan dan Penandaan Obat Bahan Alam Indonesia. BPOM RI. Jakarta.

Suparman. (2010). Formulasi Gel Kurkuminoid sebagai Antijerawat dan Aktivitas Antibakteri terhadap Staphylococcus Aureus, (Skripsi) Fakultas Farmasi Universitas Muhammadiyah Purwokerto, Yogyakarta.

Voight R. (1994). Buku Pengantar Teknologi Farmasi, Penerbit UGM Press, Yogyakarta. 